\title{
Florida's Property Tax Reform: Local Government Impacts of the Proposed Constitutional Change ${ }^{1}$
}

Rodney L. Clouser²

\section{Introduction}

This is the final publication of a series related to issues, statutory changes, and proposed constitutional changes in Florida's property tax structure. Statutory and proposed constitutional changes both were made by the Florida Legislature in 2007. Other publications in this series are FE703, FE704, FE705, and FE706 which can be found at the EDIS website (http://edis.ifas.ufl.edu).

A significant change in the estimated cost of the proposed constitutional amendment has been made since December 7, 2007. Documentation of this change was made available through state government (Economic and Demographic Research, December $18,2007)$ and is reported in this publication. In addition, this publication is intended to inform the public about the impact of proposed changes to the Florida Constitution that will be voted on by state citizens on January 29, 2008. 
water fronts, and low income seniors. Therefore, the total impacts of the statutory and proposed constitutional changes are most likely in the $\$ 23$ to $\$ 25$ billion range.

\section{Ad Valorem Tax Levies}

Ad valorem tax levies (collections) for all units of local government (county, city, school board, and dependent and independent special districts) have increased from $\$ 20.4$ billion in fiscal year 2002-03 to $\$ 30.4$ billion in fiscal year 2005-06. That represents a 49 percent increase in ad valorem tax collections in just over three years. However, when accounting for inflation increases, the real dollar increase in ad valorem collections has increased just over 27 percent (Table 2). The largest increase in taxes levied since fiscal 2002-03 have been by municipalities, school boards (operating), and countywide independent special districts.

How are ad valorem property taxes collected and distributed among units of local government? In fiscal year 2002-03, school board operating funds accounted for 38 percent of all tax collections and, in fiscal year 2005-06, this had increased to 40 percent. County government operating funds were 29 percent of collections in both fiscal years 2002-03 and 2005-06. Municipalities increased their share of the total collection of ad valorem taxes from 12 percent in fiscal 2002-03 to 13.5 percent in fiscal 2005-06. The entire distribution of ad valorem tax collections by units of local government are reported in Table 3 .

There were increases in the amount of collections (over 27 percent when adjusted for inflation over this three-year time period) and in the relative shares collected for school operating funds and municipalities. Caution needs to be practiced when reviewing information such as this. If a base year other than fiscal 2002-03 had been selected, percentage increases in budgets and relative shares of tax collections could produce entirely different results.

A more accurate assessment of the change in ad valorem tax collections would be to calculate the change on a per resident basis (per capita) expressed in real (inflation adjusted) dollars. Florida's population increased just over seven percent (from
17.1 million to 18.3 million) between 2003 and 2006 . This analysis results in the same order of tax levies between the various units of local government but at an even lower percentage increase level. For example, adjusting for inflation and accounting for population increases results in the percentage change in ad valorem taxes for municipal governments increasing by 31.1 percent, schools by 23.9 percent, and counties by 18.7 percent between 2002-03 and 2005-06. This calculation for all units of government is reported in Table 4. Again, caution needs to be practiced when using this information. Why? These values still overstate the increase in ad valorem tax collections per resident because many nonresidents pay ad valorem taxes (e.g., home owners and business owners from out-of-state). While per resident real ad valorem revenues have increased over the past three years, the actual level has not been near that reported in the popular press and media.

\section{Using Ad Valorem Taxes}

Many of the services provided by county, city, school, water management districts, etc. are paid for from ad valorem taxes. However, there is no "cookie cutter, one-size-fits-all" model for using ad valorem taxes at the local government level. However, in general, ad valorem taxes are used to pay for local government services such as executive services (administrator and associated offices), legislative services (commissioners, school boards, and associated offices), legal services (attorney fees), law enforcement, fire control, court, corrections and detention services, utility services, waste collection, resource management, roads, transportation systems and services, health, public assistance, libraries, parks and recreation, cultural and special events, education, etc.

Ad valorem taxes are used for both the physical goods needed to supply these services (e.g., gas, tires, and paper) and employees (e.g., police, firemen, and teachers). Less ad valorem taxes could lead to a flat or declining level of government services, some services could be eliminated, fewer purchases of goods by local governments could be made, and local government employees could remain constant or be reduced. This would occur as the state's population is projected to increase. It is unknown which services 
would be held constant or reduced; which goods would not be purchased; or which departments (in terms of employees) would remain at current levels, leave open positions unfilled, or eliminate employees. If reductions in services, goods, or employees are required, those decisions will be made by the elected county and city commissions, school boards, and the governing bodies of dependent and independent taxing districts. It is entirely possible that insights on future changes were observed during this past budget cycle (2007-08) when the various local government governing bodies were dealing with the statutory changes made by the legislature.

\section{Other Factors}

It needs to be made clear that the statutory changes and the proposed constitutional changes do not necessarily translate into less money available for local governments. Rather, future tax levies collected by units of local government will be less because of changes.

Revenue to support local government services also can come from other sources such as fees and assessments, which could offset property tax reductions. If this occurs, local government services might not have to be maintained at current levels or reduced at all.

Another reason that the statutory changes and the proposed constitutional changes do not necessarily translate into less money for government services is because new property is being added to the tax rolls as homes and business expand throughout the state. This can be more easily understood with a specific example. The state estimates that Alachua County will lose $\$ 18.3$ million in tax collections in tax year 2008 ( $\$ 11.1$ million, county government; \$2.1 million, schools; \$2.9 million, municipalities; and $\$ 2.2$ million, special districts). The county government will lose $\$ 11.1$ million, which represents just over 60 percent of the total tax impact for all taxing districts in the county. Approximately $\$ 8$ to $\$ 9$ million of the "loss" is projected as a result of doubling the homestead tax exemption. Yet, Alachua County government has indicated the loss they are expecting is only around $\$ 1$ million. Why? New growth in houses and businesses will generate new revenue. Local county and city governments with slow growth will experience decreased property tax revenues while local government units with rapid growth may not experience any decreases at all.

It is difficult to understand the size and scope of the numbers associated with the proposed amendment ( $\$ 23$ to $\$ 25$ billion). The total expected reduction in tax levies over the five-year period is equivalent to about 80 percent of what all units of local government collected in property tax 2006. Is that a significant amount of money? Probably. Assume your family had an income of $\$ 50,000$ per year and over the next five years you would not collect $\$ 40,000$ of that income ( $\$ 8,000$ per year), Would that be significant to you? Probably. This may help to explain why units of local government are so concerned with the proposed changes.

Sometimes public policies have unintended consequences that are not examined in detail. That may be the case with the proposed property tax changes. If property taxes decline for Floridians, individuals who itemize deductions on their federal tax returns will pay more in federal taxes. This has not been mentioned very often during the property tax debate. Even if the increased federal tax increase is small for an individual, when multiplied by hundreds of thousands of Florida tax returns (in 2005, 2.37 million Floridians itemized real estate taxes, http://www.irs.gov/pub/irs-soi/05in10fl.xls), it may become sizeable.

It is unclear how the reduction in the amount of funds for public education will be replaced. Both the Governor and members of the legislature have indicated or "promised" that public education funding will not be reduced, but they have not said how funding will be replaced. Will it be from some type of new fee or tax, a transfer from another fund, or monies reallocated from state-funded agencies and projects? No one knows for sure, and the sum of $\$ 1.56$ billion over the five-year period is significant. Likewise, the proposed changes do not explicitly explain how funding for fiscally constrained counties will be replaced or if the funds will be replaced on a dollar-for-dollar basis. 
Some people may base their support or lack of support on the proposed constitutional change on what individuals or politically active groups are telling them about the proposed amendment. Groups supporting the proposed constitutional change include the Florida Outdoor Advertising Association, the Florida Chamber of Commerce, The Associated Industries of Florida, and the Florida Association of Realtors. Another group supporting the amendment is the Political Action Committee (PAC) called "Vote Yes on 1, Save Our Homes Now". The largest contributor to date for this PAC is the Florida Association of Realtors ( $\$ 1$ million). Other significant contributions have come from Florida Power and Light Company $(\$ 500,000)$ and the Florida Chamber of Commerce $(\$ 100,000)$. Groups opposing the amendment include the Florida League of Cities, Florida Education Association, Florida Association of Professional Firefighters, the Florida AFL-CIO, the Florida PTA, and the Florida League of Women Voters. Several of these groups are supporters of a Political Action Committee called "Florida Is Our Home". No campaign contributions or expenditures have been reported by this group as of the end of December 2007.

Finally, do not assume the 2008 proposed constitutional amendment is the last word about property taxes in Florida. It seems unlikely at this time that the Florida Legislature will directly initiate changes during the next session. However, the Taxation and Budget Reform Commission (TBRC) can recommend changes to the legislature and can also place policies directly on the fall 2008 ballot. Also, there are efforts underway to place further property tax changes on the fall ballot through citizen-led initiatives.

\section{Your Vote}

The basic information that can help you determine how you will vote on January 29, 2008 has been provided in the five publications of this series. Your vote should express your personal preference. Most importantly, vote!

What is known about the proposed constitutional change is that potential tax savings for the average person will be relatively small. Savings from the proposed tangible personal property tax will most likely range between $\$ 74$ and $\$ 400$. Savings from the doubling of the homestead tax exemption might range from $\$ 150$ to $\$ 250$. Savings from the 10 percent cap on non-homesteads will be small as well. Savings from the portability provision could be several thousand dollars $(\$ 2,000$ or more). However, this provision only applies if you own a home, and substantial savings will only occur if you have a sizeable Save Our Homes ( $\mathrm{SOH}$ ) differential and decide to purchase a new home.

The bottom line is that the tax savings for the average Floridian will most likely be less than $\$ 250$ per year, or about 70 cents per day. If you are satisfied with the level and quality of local government services you receive and if you believe that your local elected officials are better able to meet the needs within the local community, then you may not support the proposed amendment. If the opposite is true, you may want to support the proposed constitutional changes. However, as mentioned in a previous publication, the proposed changes concentrate on money, not on the quality or the types of services needed at the local level. Until needs and wants can be separated by voters and politicians, there will always be the tendency to complain about taxes being too high.

\section{References}

Clouser, Rodney L. 2007. Florida's Property Tax Reform: Implications for Your Tax Bill from Proposed Constitutional Changes. Electronic Data Information Source (EDIS) FE 706. Food and Resource Economics Department, University of Florida, Gainesville, FL. http://edis.ifas.ufl.edu/FE706.

Clouser, Rodney L. 2007. Florida's Property Tax Reform: Proposed Constitutional Changes. Electronic Data Information Source (EDIS) FE 705. Food and Resource Economics Department, University of Florida, Gainesville, FL. http://edis.ifas.ufl.edu/FE705.

Clouser, Rodney L and W. David Mulkey. 2007. Florida's Property Tax Reform: Statutory Changes. Electronic Data Information Source (EDIS) FE 704. Food and Resource Economics Department, 
University of Florida, Gainesville, FL.

http://edis.ifas.ufl.edu/FE704.

Clouser, Rodney L and W. David Mulkey. 2007.

Florida's Property Tax Debate: Assessing the

Situation and Why We Are Where We Are Today.

Electronic Data Information Source (EDIS) FE 703.

Food and Resource Economics Department,

University of Florida, Gainesville, FL.

http://edis.ifas.ufl.edu/FE703.

Florida Department of Revenue. 2007. 2006

Florida Property Valuations and Tax Data June 2007. http://dor.myflorida.com/dor/property/

databook06_1.html. Visited website December 2007.

Florida Department of Revenue. 2006. 2005

Florida Property Valuations and Tax Data May 2006. http://dor.myflorida.com/dor/property/

05FLpropdata.pdf. Visited website December 2007

Florida Department of Revenue. 2006. Florida

Property Valuations and Tax Data April 2006.

http://dor.myflorida.com/dor/property/

04FLpropdata.pdf. Visited website December 2007.

Florida Department of Revenue. 2003. Florida

Property Valuations and Tax Data December 2003.

http://dor.myflorida.com/dor/property/

03FLpropdata.pdf. Visited website December 2007.

Office of Economic and Demographic Research, Florida Legislature. Revenue Estimating Conference Ad Valorem Assessments. http://edr.state.fl.us/conferences/advalorem/ SB2d\%20detail.pdf. Visited website December 2007.

U.S. Department of Commerce, Bureau of Economic Analysis. Implicit Price Deflators for

Gross Domestic Product.

http://www.bea.gov/national/nipaweb/TablePrint.asp.

Visited website December 2007. 
Table 1. Revised impacts of proposed constitutional amendment.

\begin{tabular}{|c|c|c|c|c|c|c|}
\hline Fiscal Year & $2008-09$ & $2009-10$ & $2010-11$ & $2011-12$ & $2012-13$ & 5 Year Total \\
\hline \multirow[t]{2}{*}{ Nonschool } & (N) $\$ 1.11 \mathrm{~B}$ & (N) $\$ 1.28 \mathrm{~B}$ & (N) $\$ 1.52 \mathrm{~B}$ & (N) $\$ 1.78 \mathrm{~B}$ & (N) $\$ 2.06 \mathrm{~B}$ & (N) $\$ 7.75 \mathrm{~B}$ \\
\hline & (O) $\$ 1.17 \mathrm{~B}$ & (O) $\$ 1.5 \mathrm{~B}$ & (O) $\$ 1.88 \mathrm{~B}$ & (O) $\$ 2.34 \mathrm{~B}$ & (O) $\$ 2.74 \mathrm{~B}$ & (O) $\$ 9.62 \mathrm{~B}$ \\
\hline \multirow[t]{2}{*}{ School } & (N) $\$ 161.3 \mathrm{M}$ & $(\mathrm{N}) \$ 249.2 \mathrm{M}$ & $(\mathrm{N}) \$ 312.8 \mathrm{M}$ & $(\mathrm{N}) \$ 380.6 \mathrm{M}$ & $(\mathrm{N}) \$ 451.6 \mathrm{M}$ & (N) $\$ 1.56 \mathrm{~B}$ \\
\hline & (O) $\$ 204.0 \mathrm{M}$ & (O) $\$ 387.0 \mathrm{M}$ & (O) $\$ 547.0 \mathrm{M}$ & (O) $\$ 721.0 \mathrm{M}$ & (O) $\$ 898.0 \mathrm{M}$ & (O) $\$ 2.76 \mathrm{~B}$ \\
\hline \multirow[t]{2}{*}{ Total } & (N) $\$ 1.27 \mathrm{~B}$ & (N) $\$ 1.53 \mathrm{~B}$ & (N) $\$ 1.83 \mathrm{~B}$ & (N) $\$ 2.16 \mathrm{~B}$ & (N) $\$ 2.51 \mathrm{~B}$ & (N) $\$ 9.31 \mathrm{~B}$ \\
\hline & (O) $\$ 1.37 \mathrm{~B}$ & (O) $\$ 1.88 \mathrm{~B}$ & (O) $\$ 2.43 \mathrm{~B}$ & (O) $\$ 3.06 \mathrm{~B}$ & (O) $\$ 3.64 \mathrm{~B}$ & (O) $\$ 12.38 \mathrm{~B}$ \\
\hline \multicolumn{7}{|c|}{$\begin{array}{l}(N)=\text { New estimated impacts } \\
(O)=\text { Original estimated impacts } \\
\text { Source: Office of Economic and Demographic Research }\end{array}$} \\
\hline
\end{tabular}

Table 2. Florida ad valorem taxes, by taxing unit, billion dollars, 2003-2006.

\begin{tabular}{lcccccc|}
\hline \hline Year Source & 2003 & 2004 & 2005 & 2006 & $\begin{array}{c}\text { Nominal } \\
\text { Increase }\end{array}$ & $\begin{array}{c}\text { Real } \\
\text { Increase }\end{array}$ \\
\hline County Government Operating & $\$ 6.0$ & $\$ 6.4$ & $\$ 7.6$ & $\$ 8.9$ & $48.3 \%$ & $26.8 \%$ \\
School Board Operating & $\$ 7.8$ & $\$ 8.8$ & $\$ 10.2$ & $\$ 12.1$ & $55.1 \%$ & $32.6 \%$ \\
$\begin{array}{l}\text { Independent Special Districts } \\
\text { Countywide }\end{array}$ & $\$ 1.0$ & $\$ 1.1$ & $\$ 1.3$ & $\$ 1.5$ & $50.0 \%$ & $28.2 \%$ \\
$\begin{array}{l}\text { Municipalities } \\
\begin{array}{l}\text { Municipal Service Taxing Unit } \\
\text { (MSTU) }\end{array}\end{array}$ & $\$ 2.5$ & $\$ 2.9$ & $\$ 3.4$ & $\$ 4.1$ & $64.0 \%$ & $40.2 \%$ \\
$\begin{array}{l}\text { Independent Special Districts } \\
\text { Less Than Countywide }\end{array}$ & $\$ 0.7$ & $\$ 0.8$ & $\$ 0.9$ & $\$ 1.0$ & $42.9 \%$ & $22.1 \%$ \\
$\begin{array}{l}\text { All Other Ad Valorem Taxes } \\
\text { Grand Total }\end{array}$ & $\$ 1.6$ & $\$ 1.4$ & $\$ 1.4$ & $\$ 1.8$ & $12.5 \%$ & $-3.9 \%$ \\
\hline $\begin{array}{l}\text { Sources: U.S. Department of Commerce, Bureau of Economic Analysis (2003 real dollars) and Florida } \\
\text { Department of Revenue }\end{array}$ & $\$ 20.4$ & $\$ 22.2$ & $\$ 25.7$ & $\$ 30.4$ & $25.0 \%$ & $6.8 \%$ \\
\hline \hline
\end{tabular}


Florida's Property Tax Reform: Local Government Impacts of the Proposed Constitutional....

Table 3. Percent of ad vallorem taxes, by taxing unit, Florida local governments, 2003 and 2006.

\begin{tabular}{lcc|}
\hline \hline Year Source & 2003 & 2006 \\
\hline County Government Operating & $29.0 \%$ & $29.0 \%$ \\
School Board Operating & $38.0 \%$ & $40.0 \%$ \\
Independent Special Districts Countywide & $5.0 \%$ & $5.0 \%$ \\
Municipalities & $12.0 \%$ & $13.5 \%$ \\
Municipal Service Taxing Unit (MSTU) & $3.5 \%$ & $3.0 \%$ \\
Independent Special Districts Less Than Countywide & $3.9 \%$ & $3.0 \%$ \\
All Other Ad Valorem Taxes & $7.9 \%$ & $5.9 \%$ \\
Grand Total & $100.0 \%$ & $100.0 \%$ \\
\hline \hline
\end{tabular}

Table 4. Nominal, real, and real per resident increases in property taxes, 2003-2006.

\begin{tabular}{|lrrr|}
\hline \hline Year Source & $\begin{array}{c}\text { Nominal } \\
\text { Increase } \\
2003-2006\end{array}$ & $\begin{array}{r}\text { Real } \\
\text { Increase } \\
2003-2006\end{array}$ & $\begin{array}{r}\text { Real Per Resident } \\
\text { Increase } \\
2003-2006\end{array}$ \\
\hline County Government Operating & $48.3 \%$ & $26.8 \%$ & $18.7 \%$ \\
School Board Operating & $55.1 \%$ & $32.6 \%$ & $23.9 \%$ \\
Independent Special Districts Countywide & $50.0 \%$ & $28.2 \%$ & $20.8 \%$ \\
Municipalities & $64.0 \%$ & $40.2 \%$ & $31.1 \%$ \\
Municipal Service Taxing Unit (MSTU) & $42.9 \%$ & $22.1 \%$ & $14.7 \%$ \\
Independent Special Districts Less Than Countywide & $25.0 \%$ & $6.8 \%$ & $17.0 \%$ \\
All Other Ad Valorem Taxes & $12.5 \%$ & $-3.9 \%$ & $-9.4 \%$ \\
Grand Total & $49.0 \%$ & $27.4 \%$ & $19.0 \%$ \\
\hline \hline
\end{tabular}

